\title{
Stock Market Development And Economic Growth In Hong Kong: An Empirical Investigation
}

SY Ho, University of South Africa, South Africa

NM Odhiambo, University of South Africa, South Africa

\begin{abstract}
This paper examines the relationship between stock market development and economic growth using time-series data from Hong Kong. The study uses three proxies of stock market development, namely: stock market capitalisation, stock market traded value, and stock market turnover. Given the weaknesses associated with the traditional co-integration techniques, the current study uses the recently introduced ARDL-bounds testing approach to examine the nexus between stock market development and economic growth in a dynamic setting. The empirical results show that the direction of causality between stock market development and economic growth depends on the proxy used to measure the level of stock market development. When stock market capitalisation is used as a proxy for stock market development, a distinct unidirectional causal flow from stock market development to economic growth is found to prevail, without any feedback. However, when stock market turnover is used, a causal flow from economic growth to stock market development is found to prevail in the short run and in the long run, while a causal flow from stock market development to economic growth is only found in the short run. The causality between stock market traded value and economic growth, however, failed to yield any long-run causal relationship from either direction. Only a short-run causality flow from economic growth to stock market traded value could be detected in this case.
\end{abstract}

Keywords: Hong Kong; Stock Market Development; Economic Growth

\section{INTRODUCTION}

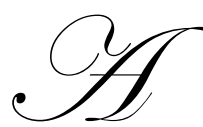

-lthough the relationship between financial development and economic growth has attracted numerous empirical studies in recent decades, the majority of these studies have focused mainly on the relationship between bank-based financial development and economic growth. Studies linking stock market development directly to economic growth are very scanty. In fact, for a very long time the concepts of financial development and bank-based financial development have been treated as synonymous.

Even the early pioneers of financial sector development - such as Ronald McKinnon and Edward Shaw did not give equal importance to the role of stock market development or bank-based financial development and economic growth. This is mainly because the McKinnon-Shaw theory was largely based on credit market development, rather than on stock market development. In fact, the theory of financial liberalisation, which was pioneered by McKinnon and Shaw (1973), has been sharply criticised by a number of scholars for ignoring the important role of the stock market in economic development (see Levine and Zervos, 1996; Singh, 1997). According to Singh, the total market capitalisation of companies quoted on the stock exchange, in a number of developing countries, increased by a factor of 20 between 1982 and 1992.

Theoretically, stock market development can promote long-term economic development in a number of different ways. By reducing the cost of mobilising savings, stock market development may facilitate investment; and hence, it leads to economic growth (see also Greenwood and Smith, 1997). According to Levine (1991) and 
Bencivenga et al. (1996), stock markets make the financial assets traded in them less risky because they allow savers to buy and sell quickly and cheaply when they wish to alter their portfolios. In addition, stock market development makes financial assets less risky and gives companies easy access to capital through equity issues. This leads to an improvement in the allocation of capital and, therefore, serves as an important channel for economic growth (see Arestis et al., 2001).

The current study examines the relationship between stock market development and economic growth using time-series data from Hong Kong. The study uses three proxies of stock market development, namely: stock market capitalisation, stock market traded value and stock market turnover, all of which are expressed as a ratio of GDP. In addition, the study uses the newly introduced ARDL-bound testing approach to examine this linkage. The ARDL-bound testing approach has been found to be more effective than the traditional cointegration techniques, especially when the sample period is relatively short. The rest of the paper is organised as follows. Section 2 traces the dynamics of stock market development and economic growth in Hong Kong, while section 3 presents a classical review of the previous studies that have been done on the relationship between stock market development and economic growth. Section 4 outlines the estimation techniques, the empirical analysis and a discussion of the results. Section 5 concludes the study.

\section{STOCK MARKET DEVELOPMENT AND ECONOMIC GROWTH IN HONG KONG}

Hong Kong had successfully been transformed from a small entrepôt into a world-class financial centre over the past few decades (Schnek, 2002; Jao, 2003). The early development of financial markets was initiated to meet the demands of trade and transhipment during the 1960s. In the 1970s, the emphasis was on the Euro-Dollar market in a different time zone; and the trend of international capital flows into Asia boosted financial activities in Hong Kong.

In 1978, Hong Kong's status as the financial gateway to the east was enhanced, when China embarked on an ambitious open-door policy. However, uncertainties shrouded Hong Kong in the 1980s. There were banking failures in the early 1980s; and the stock market crash in 1987. This was triggered by the confidence crisis at that time over Hong Kong's future after 1997, resulting in a collapse of the asset market.

Given its favourable business infrastructure, Hong Kong became the natural choice for the influx of multinational corporations' operational headquarters during the 1990s. This spun off other economic externalities, which benefited the development of Hong Kong as a financial centre (Tan et al., 2004).

By 1996, Hong Kong had become the world's seventh largest trading entity and the seventh largest stock market, the world's fifth-largest banking centre - in terms of external financial transactions - and the fifth-largest foreign exchange market in terms of average daily turnover, the world's fourth leading source of foreign direct investment, and the world's busiest container port (IMF 1997).

Regarding the stock market development, Hong Kong had its first formal stock market early in 1891, when the Association of Stockbrokers in Hong Kong was established. It was renamed the Hong Kong Stock Exchange in 1914. There have been a number of major developments since 1986. The 1987 market crash revealed flaws in the market - and this led to a complete reform of the Hong Kong securities industry - in terms of regulatory changes and infrastructural development.

As a result, the Securities and Future Commission was set up in 1989, as the sole statutory securities market regulator. Hong Kong's equity market consists of two major platforms, the Stock Exchange of Hong Kong Limited and the Hong Kong Futures Exchange, in addition to its associated clearing houses. To further increase its competiveness and meet the challenges from technological advances, various fundamental reforms of the market structure were carried out in 1999. For example, the Stock Exchange of Hong Kong and the Hong Kong Futures Exchange merged to form the Hong Kong Exchange and Clearing Ltd. During the same year, a second board, called the Growth Enterprise Market was introduced to encourage high-tech companies without a record of profitability to list on the stock exchange (see Hong Kong Exchange Fact Book, 1999). 
Hong Kong stock markets are among the most established in Asia. The market capitalisation has continuously increased from HK\$ 56,675 million in 1976 to HK\$20,942,284 million in 2010, which is more than 350 times increase over the past three decades. It is the seventh largest stock market in the world, according to the World Federation of Exchange data in 2010, slightly behind the Shanghai Stock Exchange in Mainland China.

On a global basis, the figure may account for only a small percentage relative to the financial market giants, such as the New York Stock Exchange and the London Stock Exchange. A more meaningful comparison can be drawn by the market capitalisation as a percentage of GDP. According to Table 1, the market capitalisation of the New York Stock Exchange was US\$ 11, 837.8 billion in 2009, which was the largest market capitalisation in the world. However, the market capitalisation to GDP ratio was only 0.84 . The second largest stock market in 2009 was the London Stock Exchange, which had US\$ 3,453.6 billion. However, its market capitalisation to GDP ratio was only 0.80 . While distant to the above figures, Hong Kong was on the top of the list, with its market capitalisation being almost eleven times its GDP for 2009. The second and the third stock exchanges were the Johannesburg Stock Exchange and the Singapore Exchange, with ratios of 2.8 and 2.6 respectively.

Table 1: Stock Market Capitalisation to GDP (2009)

\begin{tabular}{l|ccc}
\hline Exchange & $\begin{array}{c}\text { 2009 Domestic market } \\
\text { capitalization } \\
\text { (USD billions) }\end{array}$ & $\begin{array}{c}\text { GDP (USD } \\
\text { billions) }\end{array}$ & Market Capitalisation to GDP \\
\hline NYSE Euronext (US) & $11,837.8$ & $14,119.1$ & 0.84 \\
London SE Group & $3,453.6$ & $4,297.1$ & 0.80 \\
Tokyo SE group & $3,306.1$ & $5,068.9$ & 0.65 \\
NASDAQ OMX & $3,239.5$ & $14,119.1$ & 0.23 \\
NYSE Euronext (Europe) & $2,869.4$ & $4,158.6$ & 0.69 \\
Shanghai SE & $2,704.8$ & $4,984.7$ & 0.54 \\
Hong Kong Exchanges & $2,305.1$ & 210.6 & 10.95 \\
\hline
\end{tabular}

Source: World Federation of Exchanges, www.world-exchanges.org

This high stock market capitalisation to GDP ratio reflects the growth of Hong Kong's stock market and the growing use of equity financing. It is also worth noting that there has been a significant growth in the number of listed companies in the Hong Kong Stock Exchange during the past two decades, with an average of over 8 percent growth annually. The number of listed companies increased from 299 in 1990, to 542 in 1995. This number later increased to 790 and 1,135 in 2000 and 2005, respectively. In 2010. Hong Kong ranked $11^{\text {th }}$ in the world in terms of the number of listed companies. Table 2 shows the number of listed companies in Hong Kong between 2000 and 2010, when compared with other major stock exchanges.

Table 2: Number of Listed Companies on Exchange

\begin{tabular}{l|cccc}
\hline \multicolumn{5}{c}{ Number of Listed Companies on Exchange } \\
\hline 2000 & NYSE Euronext (US) & London SE & Tokyo SE & Hong Kong Exchanges \\
2001 & 2,468 & 2,374 & 2,096 & 790 \\
2002 & 2,400 & 2,332 & 2,141 & 867 \\
2003 & 2,366 & 2,824 & 2,153 & 978 \\
2004 & 2,308 & 2,692 & 2,206 & 1,037 \\
2005 & 2,293 & 2,837 & 2,306 & 1,096 \\
2006 & 2,270 & 3,091 & 2,351 & 1,135 \\
2007 & 2,280 & 3,256 & 2,416 & 1,173 \\
2008 & 2,297 & 3,307 & 2,414 & 1,241 \\
2009 & 1,963 & 3,096 & 2,390 & 1,261 \\
2010 & 2,327 & 3,088 & 2,335 & 1,319 \\
\hline
\end{tabular}

Source: World Federation of Exchanges, www.world-exchanges.org 
The growth of the financial sector in Hong Kong has also been accompanied by a rapid growth of the real sector. Hong Kong has achieved an "economic miracle" during the past few decades. The real per capita GDP has increased almost threefold: from HK\$ 61,605 in 1976 to HK\$ 245,536 in 2010. When Hong Kong was ceded to the British in 1842, its economic base was an entrepôt trading port for south China and the overseas Chinese community, with only limited domestic manufacturing activities. However, the civil war on the mainland China, and the ultimate communist victory in 1949, caused fundamental changes in Hong Kong. With the massive inflow of resources of labour, capital, and entrepreneurial skill - especially from Shanghai, they transformed the economy from an entrepôt to an industrial city (Krause, 1988).

In the post war era, Hong Kong developed large export-dependent domestic manufacturing sectors. In the 1980s, it gradually moved from manufacturing into banking and financial services (Young, 1992). Hong Kong has achieved rapid economic growth during the last few decades. Together with Singapore, Taiwan and South Korea, these comprise the new industrialised countries (NICs). The average growth rate in per capita real terms was 6.2 percent during the 1960s. This rate later increased to 6.4 percent in the 1970s. The average growth rates in per capita real terms during the 1980s, the 1990s and the first decade in the 2000s amounted to 5.9 percent, 2.1 percent and 3.6 percent, respectively.

\section{LITERATURE REVIEW}

Over the past two decades, the question of whether stock market development precedes economic growth, or vice versa, has been empirically tested and recorded in the literature. Most of the studies conclude that the evolution of stock market and the provision of financial intermediary services are crucial in promoting economic growth.

Atje and Jovanovic (1993), for example, ask whether financial development, especially stock market development, affects the level and the growth rate of economic activities. By using different cross-country growth regression frameworks, they find a significant correlation between economic growth and the value of stock market traded divided by GDP for 40 countries. To assess whether stock markets are merely burgeoning casinos, or whether stock markets are importantly linked to economic growth, Levine and Zervos (1996) use pooled cross-country, timeseries regressions to evaluate the relationship between stock market development and economic growth. Using data on 41 countries over the period from 1976 to 1993, they find that stock market development is positively associated with economic growth. Levine and Zervos (1998), utilizing cross-country regressions for 47 countries over a period from 1976-1993 investigate whether measures of stock market liquidity, size, volatility, and integration with world capital markets robustly correlated with measures of real activity. Their results show that the various measures of stock market activity are positively and robustly correlated with current and future rates of economic growth, and that the association is particularly strong for developing countries. They argue that stock markets may enhance growth through liquidity, which reduces investment risk and enables firms to enjoy permanent access to capital through liquid equity issues. Filer et al. (1999) investigate whether financial development causes economic growth or whether it is a consequence of increased economic activity - based on the data from 64 countries over the period from 1985 to 1997. The Granger-causality test results demonstrate that there is a strong relationship between stock market development and future economic growth for the low and lower middle income countries; but this does not hold in the higher income countries with more developed alternative financial mechanisms. They also find that there is no impact of increased equity market activity on growth in those developing countries where the lack of proper institutional framework hampers the ability of these markets to function. Therefore, in order to have a large impact in increasing long-term growth rates, they recommend that public policy and international aid should be directed towards introducing and fostering stock markets, while creating an institutional framework that is free of corruption and excessive government control. Rousseau and Wachtel (2000) examine the relationship between stock markets, banks and growth using the analysis of panels with a short time dimension to estimate vector autoregressions for a set of 47 countries with annual data from 1980 to 1995. The results show that both stock market development and banking sector development explain subsequent growth. Khan and Senhadji (2000), examine a panel of 159 countries, over the period from 1960 to 1999, on the relationship between financial depth and economic growth. The coefficient of the financial depth indicator proxied by stock market capitalization is positive and highly significant, suggesting a positive relationship between stock market development and growth. Arestis et al. (2001), while using time-series method and quarterly data from five industrialised countries, find that stock markets are able to 
contribute to long-term economic growth. However, their findings show that bank-based financial systems are more able to promote long-term growth than market-based ones. They also find that the contribution of stock markets to economic growth had been exaggerated by studies using cross-country growth regressions. Beck and Levine (2001) apply dynamic panel techniques to assess the relationship between stock markets, banks and economic growth over the period 1976-1998, in a panel of 40 countries. They find that the expansion of both banks and stock markets positively influence economic growth - even after controlling for country-specific effects and potential endogeneity. Minier (2002), based on the regression and data of Levine and Zervos (1998), investigates whether the partial correlation between growth and financial development differs based on countries' levels of financial and economic development. The study shows there is a positive correlation between stock market development and economic growth in countries with high levels of market capitalization. However, this relationship does not appear to hold for countries with low levels of market capitalisation. This finding is also supported by Rioja and Valev (2004), who examine the effects of financial development on the sources of growth in different groups of countries. Using dynamic panel techniques over 74 countries, they claim the nexus between stock market development and economic growth differs at various stages of economic development. Caporale et al. (2004) use techniques developed by Toda and Yamamoto (1995) to investigate the causal link between stock market development, financial development and economic growth. Evidence from a sample of seven countries over the period 1977Q1-1998Q4 suggests that a well developed stock market can foster growth in the long run. Arestis et al. (2005), analyze the prospective role of financial structure and financial development in economic growth for fourteen countries, utilizing a time series and dynamic heterogeneous panel methods. Their results show that for the majority of the sample countries, financial structure is significant in explaining economic growth. Adjasi and Biekpe (2006) study the effect of stock market development on economic growth in 14 African countries, using dynamic panel data analysis. Their findings are threefold. Firstly, their results show a positive relationship between stock market development and economic growth of the group of African countries. Secondly, stock markets only play a significant positive role in the growth of upper middle income African countries. Finally, on the basis of market capitalization grouping, stock market developments play a significant role in growth only for moderately capitalized markets. The results show that low income African countries and less developed stock markets need to grow more and develop their markets - in order to realize economic gains from stock markets. Akinlo and Akinlo (2009) investigate the long run and causal relationship between stock market development and economic growth for seven African countries over the period from 1980 to 2004, using the autoregressive distributed lag (ARDL) bounds test and Granger causality test within the context of VECM framework. The results of this study suggest that stock market development has a significant positive long-run impact on growth. Granger causality test within the VECM framework further shows a unidirectional relationship running from stock market development to economic growth. However, Granger causality within VAR framework shows short-run bidirectional causality between stock market development and economic growth for Cote d'Ivoire, Kenya, Morocco and Zimbabwe. In the case of Nigeria, a weak evidence of unidirectional causality running from economic growth to stock market development is found to prevail. Recently, Saci et al. (2009), utilizing dynamic panel techniques on annual panel data for 1988-2001 for 30 developing countries, to investigate the joint contribution of stock markets and banks development to economic growth. They conclude that stock market variables are positively and significantly related to economic growth, whereas the standard banking sector variables have negative effects on growth.

There are some country-specific empirical investigations, such as Thangavelu et al. (2004), N' Zué (2006), Ibrahim (2007), Agrawalla and Tuteja (2007), Chakraborty (2008), and Deb and Mukherjee (2008), Odhiambo (2011), and Zivengwa et al. (2011), among others. Thangavelu et al. (2004), employ a time-series methodology of vector autoregressive (VAR) model and Granger causality test to examine the dynamic relationship between financial development and economic growth in Australia, during the period of 1960 - 1999 in terms of bank-based and market-based structures. The results suggest that development in the financial markets causes economic growth, but there is no evidence of any causality from economic growth to financial markets. N' Zué (2006) examines the relationship between the stock market development and economic performance in Cote d'Ivoire over the period from 1976 to 2002. He finds that there is a long-run relationship between gross domestic product and stock market development. Moreover, there is a unidirectional causality running from stock market development to economic growth. Ibrahim (2007) investigates the finance-economic development relationship of Malaysia over the period of 1985-2003. Utilizing time-series econometric techniques, the study shows that the measure of stock market development is positively related to real output in the long run. In the case of India, the results of the empirical investigation are mixed. Agrawalla and Tuteja (2007) investigate the causality between stock market development 
and economic growth in India, using time-series econometric techniques. They find that there is a stable long-run relationship between stock market development and economic growth in India. They suggest that a policy relating to stock market development should be directed towards the creation of transparent and mature stock exchanges. Chakraborty (2008) examines whether stock market development and banking sector development has caused economic growth in India based on the quarterly data for the period 1996-2005. The results also suggest that there is a stable long-run relationship among stock market capitalization, bank credit and growth rate of real GDP. However, the causality test results show that causality runs form growth rate of real GDP to stock market capitalization, implying that economic growth has caused financial development in India. On the other hand, Deb and Mukherjee (2008), while investigating the relationship between stock market development and economic growth in India over the last decade or so, find that there is a strong causal flow from stock market development to economic growth. The results also show a bi-directional causality between real GDP growth rate and real market capitalization ratio. Odhiambo (2011), while using ARDL-Bounds testing procedure to investigate the dynamic causal relationship between stock market development and economic growth in South Africa over the period 1971-2007, finds that the causal relationship between stock market development and economic growth is sensitive to the proxy used for measuring the stock market development. Overall, the study finds the causal flow from stock market development to economic growth to predominate both in the short run and in the long run. Recently, Zivengwa et al. (2011) explore the causal link between stock market development and economic growth in Zimbabwe over the period 1980 to 2008. Using a time-series analysis, the results show a uni-directional causal link that runs from stock market development to economic growth. The study also shows there is an indirect transmission mechanism through the effect of stock market development on investment.

Table 3 gives a summary of the literature on both cross-country and country-specific investigations on the nexus between stock market development and economic growth.

Table 3: Summary of the Literature

\begin{tabular}{|c|c|c|c|}
\hline Author & $\begin{array}{c}\text { Country/Countries of } \\
\text { study }\end{array}$ & Methodology & Empirical Findings \\
\hline $\begin{array}{l}\text { Atje \& } \\
\text { Jovanovic } \\
(1993)\end{array}$ & $\begin{array}{l}40 \text { countries for the } \\
\text { period } 1980-1988\end{array}$ & $\begin{array}{l}\text { Cross-country growth } \\
\text { regressions }\end{array}$ & $\begin{array}{l}\text { A large effect of stock market development on the } \\
\text { level and the growth rate of economic activities. }\end{array}$ \\
\hline $\begin{array}{l}\text { Levine \& } \\
\text { Zervos (1996) }\end{array}$ & $\begin{array}{l}41 \text { countries over the } \\
\text { period } 1976-1993\end{array}$ & $\begin{array}{l}\text { Pooled cross-country, time- } \\
\text { series regressions }\end{array}$ & $\begin{array}{l}\text { Stock market development is positively associated } \\
\text { with economic growth. }\end{array}$ \\
\hline $\begin{array}{l}\text { Levine \& } \\
\text { Zervos (1998) }\end{array}$ & $\begin{array}{l}47 \text { countries from } \\
1976 \text { to } 1993\end{array}$ & Cross-country regressions & $\begin{array}{l}\text { Stock market liquidity is positively and robustly } \\
\text { correlated with current and future rates of economic } \\
\text { growth. }\end{array}$ \\
\hline $\begin{array}{l}\text { Filer et al. } \\
(1999)\end{array}$ & $\begin{array}{l}64 \text { countries over the } \\
\text { period from } 1985 \text { to } \\
1997\end{array}$ & Granger-causality tests & $\begin{array}{l}\text { A strong relationship between stock market } \\
\text { development and future economic growth for the } \\
\text { low and lower middle income countries. }\end{array}$ \\
\hline $\begin{array}{l}\text { Rousseau \& } \\
\text { Wachtel (2000) }\end{array}$ & $\begin{array}{l}47 \text { countries with } \\
\text { annual data for } 1980- \\
1995\end{array}$ & Panel vector autoregressions & $\begin{array}{l}\text { Both stock market development and banking sector } \\
\text { explain economic growth. }\end{array}$ \\
\hline $\begin{array}{l}\text { Khan \& } \\
\text { Senhadji } \\
(2000)\end{array}$ & $\begin{array}{l}159 \text { countries over the } \\
\text { period from } 1960 \text { to } \\
1999\end{array}$ & Time series analysis & $\begin{array}{l}\text { A positive relationship between stock market } \\
\text { development and growth. }\end{array}$ \\
\hline $\begin{array}{l}\text { Arestis et al. } \\
(2001)\end{array}$ & $\begin{array}{l}\text { Five industrialised } \\
\text { countries }\end{array}$ & Time series analysis & $\begin{array}{l}\text { Stock markets are able to contribute to long-term } \\
\text { economic growth. }\end{array}$ \\
\hline $\begin{array}{l}\text { Beck \& Levine } \\
(2001)\end{array}$ & $\begin{array}{l}40 \text { countries over the } \\
\text { period } 1976-1998\end{array}$ & Dynamic panel data analysis & $\begin{array}{l}\text { Expansion of both banks and stock markets has a } \\
\text { positive influence on economic growth. }\end{array}$ \\
\hline Minier (2003) & $\begin{array}{l}41 \text { countries from } \\
1976 \text { to } 1993\end{array}$ & Regression tree techniques & $\begin{array}{l}\text { Positive correlation between stock market } \\
\text { development and economic growth in countries } \\
\text { with high levels of market capitalization, but not for } \\
\text { countries with low levels of market capitalisation. }\end{array}$ \\
\hline $\begin{array}{l}\text { Rioja \& Valev } \\
(2004)\end{array}$ & 74 countries & Dynamic panel techniques & $\begin{array}{l}\text { Nexus between stock market development and } \\
\text { economic growth differs at various stages of } \\
\text { economic development. }\end{array}$ \\
\hline
\end{tabular}


Table 3: Continued

\begin{tabular}{|c|c|c|c|}
\hline $\begin{array}{l}\text { Caporale et al. } \\
\text { (2004) }\end{array}$ & $\begin{array}{l}\text { Seven countries over } \\
\text { the period 1977Q1- } \\
\text { 1998Q4 }\end{array}$ & $\begin{array}{l}\text { Vector autoregressive (VAR) } \\
\text { model }\end{array}$ & $\begin{array}{l}\text { A well developed stock market can foster growth in } \\
\text { the long run. }\end{array}$ \\
\hline $\begin{array}{l}\text { Arestis et al. } \\
(2005)\end{array}$ & 14 countries & $\begin{array}{l}\text { A time series and a dynamic } \\
\text { heterogeneous panel methods }\end{array}$ & $\begin{array}{l}\text { Financial structure is significant in explaining } \\
\text { economic growth for the majority of the sample } \\
\text { countries. }\end{array}$ \\
\hline $\begin{array}{l}\text { Adjasi \& } \\
\text { Biekpe (2006) }\end{array}$ & 14 African countries & Dynamic panel data analysis & $\begin{array}{l}\text { A positive relationship between stock market } \\
\text { development and economic growth of the group of } \\
\text { African countries. }\end{array}$ \\
\hline $\begin{array}{l}\text { Akinlo \& } \\
\text { Akinlo (2009) }\end{array}$ & $\begin{array}{l}\text { Seven African } \\
\text { countries for the } \\
\text { period 1980-2004 }\end{array}$ & $\begin{array}{l}\text { Autoregressive distributed } \\
\text { lag (ARDL) bounds test and } \\
\text { Granger causality test within } \\
\text { the context of VECM } \\
\text { framework }\end{array}$ & $\begin{array}{l}\text { Stock market development has a significant positive } \\
\text { long-run impact on growth }\end{array}$ \\
\hline $\begin{array}{l}\text { Saci et al. } \\
(2009)\end{array}$ & $\begin{array}{l}30 \text { developing } \\
\text { countries }\end{array}$ & Dynamic panel data analysis & $\begin{array}{l}\text { Stock market variables are positively and } \\
\text { significantly related to economic growth. }\end{array}$ \\
\hline $\begin{array}{l}\text { Thangavelu et } \\
\text { al. (2004) }\end{array}$ & $\begin{array}{l}\text { Australia over the } \\
\text { period of } 1960-1999\end{array}$ & $\begin{array}{l}\text { Time series methodology of } \\
\text { vector autoregressive (VAR) } \\
\text { model and Granger causality } \\
\text { test }\end{array}$ & $\begin{array}{l}\text { Development in the financial markets causes } \\
\text { economic growth. }\end{array}$ \\
\hline N'Zué (2006) & $\begin{array}{l}\text { Cote d'Ivoire over the } \\
\text { period from } 1976 \text { to } \\
2002\end{array}$ & Time series analysis & $\begin{array}{l}\text { A uni-directional causality running from stock } \\
\text { market development to economic growth. }\end{array}$ \\
\hline Ibrahim (2007) & $\begin{array}{l}\text { Malaysia over the } \\
\text { period from 1985- } \\
2003\end{array}$ & Time series analysis & $\begin{array}{l}\text { Measure of stock market development is positively } \\
\text { related to real output in the long run. }\end{array}$ \\
\hline $\begin{array}{l}\text { Agrawalla \& } \\
\text { Tuteja (2007) }\end{array}$ & India & Time series analysis & $\begin{array}{l}\text { A stable long-run relationship exits between stock } \\
\text { market development and economic growth in India. }\end{array}$ \\
\hline $\begin{array}{l}\text { Chakraborty } \\
(2008)\end{array}$ & $\begin{array}{l}\text { India over the period } \\
\text { 1996Q3 to 2005Q1 }\end{array}$ & Time series analysis & $\begin{array}{l}\text { Economic growth causes financial development in } \\
\text { India. }\end{array}$ \\
\hline $\begin{array}{l}\text { Deb \& } \\
\text { Mukherjee } \\
(2008)\end{array}$ & India & Time series analysis & $\begin{array}{l}\text { - A strong causal flow from the stock market } \\
\text { development to economic growth. } \\
\text { - A bi-directional causal relationship between real } \\
\text { market capitalization ratio and economic growth. }\end{array}$ \\
\hline $\begin{array}{l}\text { Odhiambo } \\
(2011)\end{array}$ & $\begin{array}{l}\text { South Africa over the } \\
\text { period 1971-2007 }\end{array}$ & ARDL-Bounds test & $\begin{array}{l}\text { A causal flow from stock market development to } \\
\text { economic growth predominates both in the short } \\
\text { run and in the long run. }\end{array}$ \\
\hline $\begin{array}{l}\text { Zivengwa et al. } \\
\text { (2011) }\end{array}$ & $\begin{array}{l}\text { Zimbabwe over the } \\
\text { period } 1980 \text { to } 2008\end{array}$ & Time series analysis & $\begin{array}{l}\text { A uni-directional causal link that runs from stock } \\
\text { market development to economic growth. }\end{array}$ \\
\hline
\end{tabular}

\section{ESTIMATION TECHNIQUES AND EMPIRICAL ANALYSIS}

\subsection{Cointegration - ARDL Bounds Testing Procedure}

In this study, we employ the recently developed Autoregressive Distributed Lag (ARDL) - bounds testing approach to examine the long-run cointegration relationship between each of the three proxies of stock market development and economic growth. The ARDL modelling approach was originally introduced by Perasan and Shin (1999), and later extended by Perasan et al. (2001). The ARDL model used in this study can be expressed as follows:

\section{Model 1 - Stock Market Capitalisation (STOCAP) and Economic Growth}

$$
\Delta \text { Iny } / N_{t}=a_{0}+\sum_{i=1}^{n} a_{1 i} \Delta \text { Iny } / N_{t-i}+\sum_{i=0}^{n} a_{2 i} \Delta \text { InSTOCAP } P_{t-i}+a_{3} \operatorname{Iny} / N_{t-1}+a_{4} \operatorname{InSTOCAP} P_{t-1}+\mu_{t}
$$




$$
\triangle \text { InSTOCAP } P_{t}=\beta_{0}+\sum_{i=1}^{n} \beta_{1 i} \Delta \operatorname{InSTOCAP} P_{t-i}+\sum_{i=0}^{n} \beta_{2 i} \Delta \operatorname{Iny} / N_{t-i}+\beta_{3} \operatorname{Iny} / N_{t-1}+\beta_{4 I I n S T O C A P} P_{t-1}+\mu_{t}
$$

Model 2 - Stock Market Traded Value (STRADEVL) and Economic Growth

$$
\begin{aligned}
& \Delta \operatorname{Iny} / N_{t}=\phi_{0}+\sum_{i=1}^{n} \phi_{1 i} \Delta \operatorname{Iny} / N_{t-i}+\sum_{i=0}^{n} \phi_{2 i} \Delta \operatorname{InSTRADEVL} L_{t-i}+\phi_{3} \operatorname{Iny} / N_{t-1}+\phi_{4} \operatorname{InSTRADEVL}_{t-1}+\mu_{t} \\
& \Delta \operatorname{InSTRADEVL}_{t}=\delta_{0}+\sum_{i=1}^{n} \delta_{1 i} \Delta \operatorname{InSTRADEVL} L_{t-i}+\sum_{i=0}^{n} \delta_{2 i} \Delta \operatorname{Iny} / N_{t-i}+\delta_{3} \operatorname{Iny} / N_{t-1}+\delta_{4} \operatorname{InSTRADEVL}_{t-1}+\mu_{t}
\end{aligned}
$$

Model 3 - Stock Market Turnover (STOVER) and Economic Growth

$$
\begin{aligned}
& \Delta \operatorname{Iny} / N_{t}=\alpha_{0}+\sum_{i=1}^{n} \alpha_{1 i} \Delta \text { Iny } / N_{t-i}+\sum_{i=0}^{n} \alpha_{2 i} \Delta \operatorname{InSTOVER} R_{t-i}+\alpha_{3} \operatorname{Iny}_{1} / N_{t-1}+\alpha_{4} \operatorname{InSTOVER}_{t-1}+\mu_{t} \\
& \Delta \operatorname{InSTOVER}_{t}=\lambda_{0}+\sum_{i=1}^{n} \lambda_{1 i} \Delta \operatorname{InSTOVER}_{t-i}+\sum_{i=0}^{n} \lambda_{2 i} \Delta \operatorname{Iny} / N_{t-i}+\lambda_{3} \operatorname{Iny} / N_{t-1}+\lambda_{4} \operatorname{InSTOVER}_{t-1}+\mu_{t}
\end{aligned}
$$

Where: Iny $=\log$ of per capita real GDP; InSTOCAP $=\log$ of stock market capitalisation; InSTRADV $=\log$ of stock market traded value; InSTOV $=\log$ of stock market turnover; $\mu_{\mathrm{t}}=$ white noise error term; $\Delta=$ first difference operator.

The bounds testing procedure is based on the joint F-statistic (or Wald statistic) for cointegration analysis. The null hypothesis of no cointegration among the variables in equations (1) - (3) is, therefore, tested against the alternative hypothesis. If the computed test statistic exceeds the upper critical bounds value, then the Ho hypothesis is rejected. If the F-statistic is lower than the lower bounds value, then the null hypothesis of no cointegration cannot be rejected. If the F-statistic falls within the bounds, then the cointegration test becomes inconclusive.

\subsection{Granger Non-Causality Test}

Once the long-run relationships have been identified in section 4.1, the next step is to examine the short-run and long-run Granger-causality between economic growth and the three proxies of stock market development -using the following model (see Odhiambo, 2009; Narayan and Smyth, 2008).

Model 1 - Stock Market Capitalisation (STOCAP) and Economic Growth

$$
\begin{aligned}
& \Delta \operatorname{Iny} / N_{t}=a_{0}+\sum_{i=1}^{n} a_{1 i} \Delta \operatorname{Iny} / N_{t-i}+\sum_{i=0}^{n} a_{2 i} \Delta \operatorname{InSTOCAP} P_{t-i}+\operatorname{ECM}_{t-1}+\mu_{t} \\
& \Delta \operatorname{InSTOCAP} P_{t}=\beta_{0}+\sum_{i=1}^{n} \beta_{1 i} \Delta \operatorname{InSTOCAP} P_{t-i}+\sum_{i=0}^{n} \beta_{2 i} \Delta \operatorname{Iny} / N_{t-i}+\operatorname{ECM}_{t-1}+\mu_{t}
\end{aligned}
$$




\section{Model 2 - Stock Market Traded Value (STRADEVL) and Economic Growth}

$$
\Delta \operatorname{Iny} / N_{t}=\phi_{0}+\sum_{i=1}^{n} \phi_{1 i} \Delta \operatorname{Iny} / N_{t-i}+\sum_{i=0}^{n} \phi_{2 i} \Delta \operatorname{InTRADEVL} L_{t-i}+E C M_{t-1}+\mu_{t}
$$

$\Delta \operatorname{InTRADEVL} L_{t}=\delta_{0}+\sum_{i=1}^{n} \delta_{1 i} \Delta \operatorname{InTRADEVL} L_{t-i}+\sum_{i=0}^{n} \delta_{2 i} \Delta \operatorname{Iny} / N_{t-i}+E_{C M} M_{t-1}+\mu_{t}$

Model 3 - Stock Market Turnover (STOVER) and Economic Growth

$$
\begin{aligned}
& \Delta \operatorname{Iny} / N_{t}=\alpha_{0}+\sum_{i=1}^{n} \alpha_{1 i} \Delta \operatorname{Iny} / N_{t-i}+\sum_{i=0}^{n} \alpha_{2 i} \Delta \operatorname{InSTOVER} R_{t-i}+\operatorname{ECM}_{t-1}+\mu_{t} \\
& \Delta \operatorname{InSTOVER}{ }_{t}=\lambda_{0}+\sum_{i=1}^{n} \lambda_{1 i} \Delta \operatorname{InSTOVER} R_{t-i}+\sum_{i=0}^{n} \lambda_{2 i} \Delta \operatorname{Iny} / N_{t-i}+E_{C M}+\mu_{t-1}
\end{aligned}
$$

Where $\mathrm{ECM}_{\mathrm{t}-1}=$ the lagged error-correction term obtained from the long-run equilibrium relationship.

The direction of causality, in this case, is determined by the F-statistic and the lagged error-correction term. While the $\mathrm{t}$ statistic on the coefficient of the lagged error-correction term represents the long-run causal relationship, the F statistic on the explanatory variables represents the short-run causal effect (see Odhiambo, 2009). Although the error-correction term has been incorporated into all the equations (4) - (6), only equations where the null hypothesis of no cointegration is rejected will be estimated with an error-correction term (see also Narayan and Smyth, 2006; Morley, 2006).

\subsection{Data Source and Definition of Variables}

\section{Data Sources}

Annual time series data, which cover the 1980 and 2010 period, have been used in this study. The data have been obtained from different sources, including World Development Indicators (2011), Hong Kong Exchange Fact Book (2010), and Hong Kong Statistical Tables (2011).

\section{Definition of Variables}

i) Economic Growth - The economic growth variable is measured by the real per capita GDP.

ii) Stock Market Development (STK/GDP) - The stock market development is proxied by three proxies, namely: the stock market capitalisation, stock market traded value and stock market turnover; all of which are expressed as a ratio of GDP.

\subsection{Stationarity Tests}

The results of the stationarity tests at level (not presented here) show that all variables are non-stationary at level. Having found that the variables are not stationary at level, the next step is to difference the variables once, in order to perform stationarity tests on differenced variables. The results of the stationarity tests on differenced variables are presented in Tables 4 and 5. 
Table 4: Stationarity Tests of Variables on First Difference - Phillips-Perron (PP) Test

\begin{tabular}{|l|c|c|c|}
\hline \multicolumn{2}{|c|}{ Variable } & No Trend & Trend \\
\hline Phillips-Perron (PP) & $-4.732612^{* * *}$ & $-4.935785^{* * *}$ & Stationarity Status \\
\hline DLy/N & $-6.812150^{* * *}$ & $-6.837489 * * *$ & Stationary \\
\hline DLSCAP & $-7.332825 * * *$ & $-7.377276^{* * *}$ & Stationary \\
\hline DLSTKTV & $-7.955019 * * *$ & $-7.669852 * * *$ & Stationary \\
\hline DLSTOV &
\end{tabular}

Note: $* * *$ denotes $1 \%$ level of significance.

Table 5: Stationarity Tests of Variables on First Difference - Dickey-Fuller - GLS Test

\begin{tabular}{|l|c|c|c|}
\hline \multicolumn{1}{|c|}{ Variable } & No Trend & Trend & Stationarity Status \\
\hline DLy/N & $-3.837601 * * *$ & $-4.990026 * * *$ & Stationary \\
\hline DLSCAP & $-6.120617 * * *$ & $-5.808433 * * *$ & Stationary \\
\hline DLSTKT & $-5.126019 * * *$ & $-6.778690 * * *$ & Stationary \\
\hline DLSTOV & $-7.048763 * * *$ & $-5.561221 * * *$ & Stationary \\
\hline
\end{tabular}

Note: 1) Critical values for Dickey-Fuller GLS test are based on Elliot-Rothenberg-Stock (1996, Table 1).

2) $* * *$ denotes $1 \%$ level of significance.

The results reported in Tables 4 and 5 show that after differencing the variables once, all the variables are found to be stationary. The Phillips-Perron and DF-GLS tests applied to the first difference of the data series reject the null hypothesis of non-stationarity for all the variables used in this study. It is, therefore, worth concluding that all the variables are integrated of order one.

\subsection{ARDL-bounds Testing Procedure}

The ARDL-bounds testing procedure involves two steps. In the first step, the order of lags on the first differenced variables in equations (1) - (3) is obtained from the unrestricted equations by using the Akaike Information Criterion and the Schwartz Bayesian Criterion. In the second step, we apply a bound's F-test to equations (1) - (3), in order to establish the long-run relationship between the variables under study. The results of the bounds test are reported in Table 6.

Table 6: Bounds F-test for Cointegration

\begin{tabular}{|c|c|c|c|c|c|c|}
\hline Dependent variable & & nction & \multicolumn{4}{|c|}{ F-test statistic } \\
\hline \multicolumn{7}{|c|}{ Model 1 - Stock Market Capitalisation (STOCAP) and Economic Growth } \\
\hline DLy/N & \multicolumn{2}{|c|}{ DLy/N(STOCAP ) } & \multicolumn{4}{|c|}{$6.1266 * * *$} \\
\hline DLSTOCAP & \multicolumn{2}{|c|}{ DLSTOCAP $(\mathrm{y} / \mathrm{N})$} & \multicolumn{4}{|c|}{2.1020} \\
\hline \multicolumn{7}{|c|}{ Model 2 - Stock Market Traded Value (TRADEVL) and Economic Growth } \\
\hline $\mathrm{y} / \mathrm{N}$ & \multicolumn{2}{|c|}{$\mathrm{y} / \mathrm{N}(\mathrm{STRADEVL})$} & \multicolumn{4}{|c|}{$8.2436 * * *$} \\
\hline TRADEVL & \multicolumn{2}{|c|}{ TRADEVL $(\mathrm{y} / \mathrm{N})$} & \multicolumn{4}{|c|}{0.8746} \\
\hline \multicolumn{7}{|c|}{ Model 3 - Stock Market Turnover (STOVER) and Economic Growth } \\
\hline $\mathrm{y} / \mathrm{N}$ & \multicolumn{2}{|c|}{$\mathrm{y} / \mathrm{N}(\mathrm{STOVER})$} & \multicolumn{4}{|c|}{2.9346} \\
\hline STOVER & \multicolumn{2}{|c|}{ STOVER $(\mathrm{y} / \mathrm{N})$} & \multicolumn{4}{|c|}{$8.0555 * * *$} \\
\hline \multicolumn{7}{|l|}{ Asymptotic Critical Values } \\
\hline & \multicolumn{2}{|l|}{$1 \%$} & \multicolumn{2}{|l|}{$5 \%$} & \multicolumn{2}{|l|}{$10 \%$} \\
\hline & $\mathbf{I}(\mathbf{0})$ & $\mathbf{I}(\mathbf{1})$ & $\mathbf{I}(\mathbf{0})$ & $\mathbf{I}(\mathbf{1})$ & $\mathbf{I}(\mathbf{0})$ & $\mathbf{I}(\mathbf{1})$ \\
\hline Pesaran et al. (2001), p. 300, Table CI(ii) Case II & 4.94 & 5.58 & 3.62 & 4.16 & 3.02 & 3.51 \\
\hline
\end{tabular}

Note: $* * *$ denotes statistical significance at the $1 \%$ level.

The results reported in Table 6 show that the cointegration relationship between stock market development and economic growth differs among the proxies used to measure the stock market development. When the stock market capitalisation is used as a proxy for the stock market development, the calculated F-statistic is found to be higher than the upper-bound critical value in the economic growth equation, but not in the stock market capitalisation equation. Likewise, when the stock market traded value is used as a proxy for the stock market 
development, the calculated F-statistics exceeds the upper-bound critical value in the economic growth equation, but not in the stock market development equation. However, when the stock market turnover is used, the calculated Fstatistic is found to be higher than the upper-bound critical value in the stock market development, but not in the economic growth equation.

\subsection{Analysis of Causality Test Based on Error-Correction Model}

Since a long-run relationship has been found between [SCAP, y]; [STKT, y] and [STOV, y], we can now proceed with the causality test - by incorporating the lagged error-correction term into equations (7), (9) and (12), respectively. The causality in this case is examined through the significance of the coefficient of the lagged errorcorrection term and the joint significance of the lagged differences of the explanatory variables, using the Wald test. The results of these causality tests are reported in Table 7.

Table 7: Granger Non-causality Test

\begin{tabular}{|c|c|c|c|c|}
\hline \multicolumn{5}{|c|}{ Model 1 - Stock Market Capitalisation (STOCAP) and Economic Growth } \\
\hline $\begin{array}{l}\text { Dependent } \\
\text { Variable }\end{array}$ & Causal Flow & F-statistic & t-test on ECM & $\mathrm{R}^{2}$ \\
\hline $\begin{array}{l}\text { Economic } \\
\text { growth }(\mathrm{y} / \mathrm{N})\end{array}$ & $\begin{array}{l}\text { Stock Market Capitalisation }(\text { STOCAP) } \rightarrow \\
\text { Economic Growth }(\mathrm{y} / \mathrm{N})\end{array}$ & $4.4637(0.0288)^{* *}$ & $-4.326 * * *$ & 0.88 \\
\hline $\begin{array}{l}\text { Stock Market } \\
\text { Capitalisation } \\
\text { (STOCAP) }\end{array}$ & $\begin{array}{l}\text { Economic Growth }(y / N) \rightarrow \text { Stock Market } \\
\text { Capitalisation }(\text { STOCAP) }\end{array}$ & $1.1495(0.4421)$ & - & 0.64 \\
\hline \multicolumn{5}{|c|}{ Model 2 - Stock Market Traded Value (TRADEVL) and Economic Growth } \\
\hline $\begin{array}{l}\text { Dependent } \\
\text { Variable }\end{array}$ & Causal Flow & F-statistic & t-test on ECM & $\mathrm{R}^{2}$ \\
\hline $\begin{array}{l}\text { Economic } \\
\text { Growth }(y / N)\end{array}$ & $\begin{array}{l}\text { Stock Market Traded Value (TRADEVL) } \\
\rightarrow \text { Economic Growth }(\mathrm{y} / \mathrm{N})\end{array}$ & $1.1507(0.4295)$ & 1.349 & 0.59 \\
\hline $\begin{array}{l}\text { Stock } \text { Market } \\
\text { Traded Value } \\
\text { (TRADEVL) }\end{array}$ & $\begin{array}{l}\text { Economic Growth }(\mathrm{y} / \mathrm{N}) \rightarrow \text { Stock Market } \\
\text { Traded Value }(\text { TRADEVL) }\end{array}$ & $4.7826(0.0103)^{* * *}$ & - & 0.70 \\
\hline \multicolumn{5}{|c|}{ Model 3 - Stock Market Turnover (STOVER) and Economic Growth } \\
\hline $\begin{array}{l}\text { Dependent } \\
\text { Variable }\end{array}$ & Causal Flow & F-statistic & t-test on ECM & $\mathrm{R}^{2}$ \\
\hline $\begin{array}{l}\text { Economic } \\
\text { Growth }(y / N)\end{array}$ & $\begin{array}{lll}\text { Stock Market Turnover } & \text { (STOVER) } & \rightarrow \\
\text { Economic Growth }(\mathrm{y} / \mathrm{N}) & & \end{array}$ & $4.4942(0.0283)^{* *}$ & - & 0.36 \\
\hline $\begin{array}{l}\text { Stock Market } \\
\text { Turnover } \\
\text { (STOVER) }\end{array}$ & $\begin{array}{l}\text { Economic Growth(y/N) } \rightarrow \text { Stock Market } \\
\text { Turnover }(\text { STOVER) }\end{array}$ & $3.6757(0.0364)^{* *}$ & $-3.128 * * *$ & 0.42 \\
\hline
\end{tabular}

The empirical results reported in Table 7 show that when stock market capitalisation is used as a proxy for stock market development, a unidirectional causal flow from stock market development to economic growth is found to prevail in the short run and in the long run, without any feedback. This finding is confirmed by the coefficient of the error-correction term and the F-statistic, which are both statistically significant in the economic growth function, but not in the stock market capitalisation function. However, when stock market turnover is used, a causal flow from economic growth to stock market development is found to prevail in the long run and in the short run. This is supported by the F-statistic and the coefficient of the error-correction term, which are both statistically significant in the stock market development function, but not in the economic growth function. In addition, there is a short-run feedback casual flow from stock market development to economic growth - as supported by the F-statistic, which is statistically significant in the economic growth function. The causal relationship between stock market traded value and economic growth, however, only reveals a short-run causal flow from economic growth to stock market traded value. 


\section{CONCLUSION}

In this paper we have examined the causal relationship between stock market development and economic growth - using annual time-series data from Hong Kong. The study uses three proxies to measure the development of the stock market, namely: the stock market capitalisation, stock market traded value and the stock market turnover, all of which are expressed as a ratio of GDP. Unlike some of the previous studies, the study uses the recently introduced ARDL-bounds test to examine this linkage. The empirical results show that the direction of causality between stock market development and economic growth depends on the proxy used to measure the level of stock market development. When stock market capitalisation is used as a proxy for stock market development, a unidirectional causal flow from stock market development to economic growth is found to prevail, without any feedback. This applies irrespective of whether the causality is tested in the short run or in the long run. However, when stock market turnover is used, a causal flow from economic growth to stock market development is found to prevail in the short run and in the long run, while a feedback causal flow from stock market development to economic growth is only found in the short run. The causality between stock market traded value and economic growth, however, fails to yield any long-run causal relationship from either direction. Only a short-run causality flow from economic growth to stock market traded value is detected in this case.

\section{AUTHOR INFORMATION}

SY Ho, Department of Economics, University of South Africa, P.O Box 392, UNISA, 0003, Pretoria, South Africa. E-mail: hosy@unisa.ac.za / alicehosinyu@gmail.com

Prof N. M. Odhiambo, Department of Economics, University of South Africa, P.O Box 392, UNISA, 0003, Pretoria, South Africa. E-mail: odhianm@unisa.ac.za / nmodhiambo@gmail.com. Corresponding author.

\section{REFERENCES}

1. Adjasi, C. and Biekpe, N. (2006), "Stock Market Development and Economic Growth: The Case of Selected African Countries" African Development Review Volume 18, Issue 1, 144-161, April 2006.

2. Agrawalla, R. K. and Tuteja, S. K. (2007), "Causality Between Stock Market Development and Economic Growth: A Case Study of India" Journal of Management Research, 7, 158-168.

3. Akinlo, A. E. and Akinlo, O. O. (2009), "Stock Market Development and Economic Growth: Evidence from Seven Sub-Sahara African Countries" Journal of Economics and Business 61 (2009) 162-171.

4. Arestis, P., Demetriades, P.O. and Luintel, K. B. (2001), "Financial Development and Economic Growth: The Role of Stock Markets" Journal of Money, Credit and Banking 33(1): 16-41.

5. $\quad$ Arestis, P., Luintel, A. D. and Luintel, K. B. (2005), "Financial Structure and Economic Growth". Working Paper No. 06/05, Centre for Economic and Public Policy, University of Cambridge, June.

6. Atje, R. and Jovanovic, B. (1993), "Stock Market and Development" European Economic Review 37: 623640.

7. Beck, T. and Levine, R. (2001), "Stock Markets, Banks and Growth: Correlation or Causality" Policy Research Working Papers 2670, Washington DC: World Bank.

8. Bencivenga, V.R., Smith, B.D. and Starr, R.M. (1996), "Equity Markets, Transaction Costs and Capital Accumulation: An Illustration" World Bank Economic Review 10 (May): 241-65.

9. Caporale, G. M., Howells, P.G. and Soliman, A.M. (2004), "Stock Market Development and Economic Growth: The Causal Linkages" Journal of Economic Development 29(1): 33-50.

10. Chakraborty, I. (2008). "Does Financial Development Cause Economic Growth? The Case of India.” South Asia Economic Journal, 9, 109-139.

11. Deb, S.G. and Mukherjee, J. (2008), "Does Stock Market Development Cause Economic Growth? Time Series Analysis for Indian Economy." International Research Journal of Finance and Economics, 21, 142149.

12. Filer, R., Hanonsek, J. and Campas, N. (1999), “Do Stock Markets Promote Growth?” Working Paper No. 267, (September).

13. Greenwood, J. and Smith, B. (1997), "Financial Markets in Development and the Development of Financial Markets" Journal of Economic Dynamics and Control 21 (January): 145-82. 
14. Hong Kong Exchange Fact Book, Various issues.

15. Ibrahim M. H., (2007), "The Role of the Financial Sector in Economic Development: the Malaysian Case." International Review of Economics (2007) 54: 463-483.

16. IMF (1997), "Hong Kong, China: Growth, Structural Change, and Economic Stability during the Transition," Occasional Paper No. 152.

17. Jao, Y.C. (2003), "Financial Reform in Hong Kong." The International Handbook on Financial Reform. Edward Elgar Publishing, Cheltenham (Chapter 6).

18. Khan, M. S. and Senhadji, A. S. (2000), "Financial Development and Economic Growth: An Overview". IMF Working Paper No. WP/00/209, International Monetary Fund, December, USA.

19. Krause, L. B. (1988), "Hong Kong and Singapore: Twins or Kissing Cousins?”, Economic Development and Cultural Change Vol. 36, No. 3, S45-S66.

20. Levine, R. (1991), "Stock Markets, Growth and Tax Policy”, Journal of Finance 46 (September): 1445-65.

21. Levine, R. and Zervos, S. (1996), "Stock Market Development and Long Run Growth" World Bank Economic Review 10 (2).

22. Levine, R. and Zervos, S. (1998), "Stock Markets, Banks and Economic Growth" American Economic Review 98 (June): 537-58.

23. McKinnon, R. I. (1973), Money and Capital in Economic Development, Washington, D.C.: The Brookings Institution.

24. Minier, J. (2003), “Are Small Stock Markets Different?” Journal of Monetary Economics 50:1593-1602.

25. Morley, B. (2006), "Causality Between Economic Growth and Migration: An ARDL Bounds Testing Approach", Economics Letters 90, 72-76.

26. Narayan, P.K. and Smyth, R. (2006), "Higher Education, Real Income and Real Investment in China: Evidence From Granger Causality Tests", Education Economics 14, 107-125.

27. Narayan, P.K. and Smyth, R. (2008), "Energy Consumption and Real GDP in G7 Countries: New Evidence From Panel Cointegration With Structural Breaks”, Energy Economics 30, 2331-2341.

28. N' Zué, F. (2006), "Stock Market Development and Economic Growth: Evidence from Cote D' Ivoire." Africa Development Review 18(1): 123-143.

29. Odhiambo, NM (2009), "Energy Consumption and Economic Growth in Tanzania: An ARDL Bounds Testing Approach", Energy Policy, Vol. 37, Issue 2.

30. Odhiambo, NM (2011), "Capital Market Development and Economic Growth: Empirical Evidence from South Africa", Corporate Ownership and Control, Vol. 8, Number 2.

31. Pesaran, M. and Shin, Y. (1999), "An Autoregressive Distributed Lag Modeling Approach to Cointegration Analysis" in S. Strom, (ed) Econometrics and Economic Theory in the $20^{\text {th }}$ Century: The Ragnar Frisch centennial Symposium, Cambridge University Press, Cambridge.

32. Pesaran, M., Shin, Y. and Smith, R. (2001), "Bounds Testing Approaches to the Analysis of Level Relationships", Journal of Applied Econometrics 16, 289-326.

33. Rioja, F. and N. Valev (2004), "Finance and the Sources of Growth at Various Stages of Economic Development" Economic Enquiry 42 (1): 127-40.

34. Roussean, P.L. and Wachtel, P. (2000), "Equity Markets and Growth: Cross-Country Evidence on Timing and Outcomes, 1980-1995" Journal of Business and Finance 24 (Nov.): 1933-57.

35. Saci, K., Giorgioni, G. and Holden, K. (2009), "Does Financial Development Affect Growth?” Applied Economics 41: 1701-1707.

36. Schenk, C.R. (2002), "Banks and the Emergence of Hong Kong as an International Financial Center." Journal of International Financial Markets, Institutions and Money, 12, 321-340.

37. Shaw, E. S. (1973), Financial deepening in economic development. New York: Oxford University Press.

38. Singh, A. (1997),"Stock Market, Financial Liberalisation and Economic Development", Economic Journal 107 (May): 771-82.

39. Tan, C.H., Lim, J. and Chen, W. (2004), "Competing International Financial Centers: a Comparative Study Between Hong Kong and Singapore.” ISEAS conference proceeding in November 2004.

40. Thangavelu, S. M., Jiunn, A.B. and James (2004), "Financial Development and Economic Growth in Australia: an Empirical Analysis." Empirical Economics (2004) 29:247-260.

41. World Federation of Exchanges, www.world-exchanges.org, Retrieved on 18 Sep 2011.

42. Young, A. (1992), "A Tale of Two Cities: Factor Accumulation and Technical Change in Hong Kong and Singapore." NBER Macroeconomics Annual 1992 Vol. 7, 13-64. 
43. Zivengwa, T., Mashika, J., Bokosi, F.K. and Makova, T. (2011), "Stock Market Development and Economic Growth in Zimbabwe." International Journal of Economics and Finance Vol.3, No.5, October 2011. 